\title{
A case of galactosemia misdiagnosed as cow's milk intolerance
}

\author{
Roberto Della Casa ${ }^{1 *}$, Carla Ungaro', Emma Acampora ${ }^{1}$, Claudio Pignata ${ }^{1}$, Pietro Vajro², Mariacarolina Salerno ${ }^{1}$, \\ Francesca Santamaria ${ }^{1}$ and Giancarlo Parenti ${ }^{1}$
}

\begin{abstract}
We report on a female patient affected by galactosemia in whom the diagnosis was obscured by the concomitant presence of manifestations suggesting a cow's milk intolerance. This case exemplifies the problems in reaching a correct diagnosis in patients with metabolic diseases.
\end{abstract}

Keywords: Galactosemia, Cow's milk intolerance, Metabolic disease.

\section{Introduction}

The metabolic diseases are a clinically heterogeneous group of genetic disorders characterized by variable involvement of multiple organs and systems. As the clinical presentations of these disorders are often non-specific and may mimic other diseases, it is not uncommon that metabolic patients are not correctly recognized and that there is a substantial delay between onset of clinical manifestations and diagnosis. This is also due to the fact that metabolic diseases are rare disorders, in some cases with an extremely low prevalence, and are poorly known to many physicians.

Here we present a case of galactosemia that exemplifies the difficulties in achieving a correct diagnosis when clinical manifestations are overshadowed by concomitant disorders.

\section{Case report}

$\mathrm{FB}$, a female, was born to non-consanguineous parents. Her mother was affected by epilepsy and assumed anticonvulsants (carbamazepine) throughout pregnancy. She was born at 37 weeks of gestation. Delivery was uneventful.

After birth she was fed with a standard formula. Jaundice became evident in the first few days, with a total bilirubin of $15.5 \mathrm{mg} / \mathrm{dl}$ at 4 days, and was treated with phototherapy. At 7 days she was referred to a neonatal

\footnotetext{
* Correspondence: roberto.dellacasa@unina.it

${ }^{1}$ Department of Pediatrics, Federico II University, Via S. Pansini 5, 80131

Naples, Italy

Full list of author information is available at the end of the article
}

intensive care unit of a Hospital in Naples because of poor feeding, recurrent vomiting, and abdominal distention. Routine biochemistry showed the presence of defective coagulation (PT 27\%), modest hypertransaminasemia (AST $156 \mathrm{U} / \mathrm{L} ;$ ALT $188 \mathrm{U} / \mathrm{L}$ ), and a transient hyperammonemia $(202 \mathrm{mcrg} / \mathrm{dl})$ that was not detected in subsequent determinations. Biochemical analyses to detect causes of infectious diseases were negative. Screenings for metabolic disorders (blood gas analysis, plasma acylcarnitine profile by tandem mass spectrometry, plasma amino acids, urinary orotic acid and organic acids, and a screening for congenital defects of glycosylation) were all normal or non-informative. Brain, heart and abdominal ultra-sound scans were normal. An ophthalmoscopy was also normal.

During the period in the intensive care unit she was fed with a low-protein, lactose-free, hydrolysate formula for 9 days, until the age of 16 days, with progressive clinical improvement and complete recovery from the biochemical abnormalities. This formula was chosen in the hypothesis of a cow's milk intolerance because of the presence of vomiting. Considering the occasional detection of hyperammonemia, the daily protein intake was restricted.

At the age of 16 days the hydrolysate formula was interrupted and a standard formula feeding was re-introduced, still with a reduced intake of proteins. Again, vomiting and anorexia occurred, further supporting the hypopthesis of cow's milk intolerance. Thus, the same protein hydrolysate formula used earlier was resumed and continued in the following months. 
She was discharged from the Hospital at the age of 40 days, with a low-protein hydrolysate formula. At that time routine biochemical analyses, including blood ammonia and coagulation were normal.

She was referred to our Department at the age of 3 months and 20 days for further diagnostic work-up, specifically focused on possible causes of hyperammonemia. During her stay at our Department all biochemical analyses and screenings for metabolic disorders, including urea cycle defects and other possible causes of hyperammonemia, were normal or negative.

She was therefore discharged from our Department with a protein hydrolysate formula, this time with a normal intake of proteins and calories, and followed with periodic admissions to our Day-Hospital.

At the age of 8 months a formula containing cow's milk proteins was reintroduced. Once again, after 2 weeks the patient presented with anorexia and vomiting and on a follow-up biochemical check-up hypertransaminasemia (AST $626 \mathrm{U} / \mathrm{L} ;$ ALT $800 \mathrm{U} / \mathrm{L}$ ), hyperbilirubinemia (7.4 total; 3.4 conjugated), mild hypoalbuminemia $(3.6 \mathrm{~g} / \mathrm{dl})$, impaired coagulation (PT 31\%; INR 2.6; aPTT $51.5 \mathrm{sec}$; fibrinogen 151; ATIII 157) were detected. At that time a Clinitest in urines was positive, suggesting the diagnosis of galactosemia. The diagnosis of galactosemia was confirmed by the assay of galactose-1-phosphate uridyltransferase in erythrocytes, showing a highly reduced activity (1.0 $\mathrm{U} / \mathrm{g} \mathrm{Hb}$; normal values $\geq 2.3$ ). The levels of galactose1-phosphate in erythrocytes were $9.40 \mathrm{mg} / \mathrm{dl}$ (vn: 0.00 - 0.24 mg/dl).

A lactose-free formula was started and continued for the following months, with rapid and complete normalization of the biochemical markers (AST 114 U/ L; ALT $316 \mathrm{U} / \mathrm{L}$; total bilirubin $1.9 \mathrm{mg} / \mathrm{dl}, 0.82$ conjugated; PT 93\%; INR 1.06; aPTT 34.3 sec; fibrinogen 227; ATIII 127).

\section{Conclusions}

This case emphasizes the importance of thinking to rare metabolic disorders in the differential diagnosis of patients presenting with relatively non-specific symptoms. Particular attention should be paid to the clinical course and to its correlations with dietary changes. In our patient the diagnosis of galactosemia was obscured by the concomitant presence of manifestations suggesting a cow's milk intolerance.

Galactosemia is an inherited metabolic disorder, due to the deficiency of the enzyme galactose-1-phosphate uridyltransferase and with an estimated prevalence that ranges between 1 in 30,000 and 1 in 60,000 births [1]. The clinical presentations is typically characterized by severe liver involvement, that may progress to fatal liver failure, but manifestations related to the involvement of the gastro-intestinal tract, such as those seen in our patient, are common. The occurrence of sepsis in untreated neonates, mainly due to E.coli, is also frequently reported. Cataract is also a relatively frequent (14\%) finding in galactosemia [2]. The diagnosis is based on the identification of clinical and biochemical manifestations of liver disease, on screening tests (clinitest in urines, galactose-1-phosphate in erythrocytes), on the biochemical assay that demonstrates the specific enzymatic defect in blood erythrocytes, and on the molecular analysis of the GALT gene.

The treatment of galactosemia is based on the elimination of galactose and galactose-containing foods, that results in complete recovery.

In our patient the presenting symptoms, particularly gastro-intestinal signs such as vomiting on assumption of standard formulas, and the clinical response to repeated dietary changes initially supported the diagnosis of cow's milk intolerance, a very common disorder in infancy. On the other hand the use of commercial protein hydrolysate formulas, which are generally free from lactose and galactose, prevented the occurrence of clinically overt manifestations of the underlying metabolic disease, until a standard formula was re-introduced at the age of 8 months.

Other factors also contributed to mask the manifestations of galactosemia. In the first few days the presence of biochemical signs of liver disease were erroneously attributed to the maternal use of antiepileptic drugs during pregnancy. It is known that some antiepileptic drugs, such as phenobarbital, fenitoin, carbamazepine, may cross the placental barrier and induce microsomal enzymes in fetal liver. An unexplained liver disease may also be the sign of a broad range of distinct syndromes, including familial hemophagocytosis [3] and complex autoimmune disorders [4,5].

In addition, the absence in the first weeks of life of lens opacities, a typical and peculiar finding in galactosemia, that may raise the suspect of galactosemia, contributed to the delay in achieving the correct diagnosis.

The clinical presentation of galactosemia is characterized by relatively non-specific signs that may be attributed to other disorders. This is a common finding in many metabolic diseases that are characterized in general by complex phenotypes, involving several organs and systems, such as the central nervous system $[6,7]$, the respiratory tract $[8-11]$, the gastrointestinal tract and liver [12-14], the muscolo-skeletal system [15-18], and the immune system. Such a wide variability and involvement of different systems may be confusing in the diagnostic approach to patients with metabolic disorders.

Simple and widely available screening tests, such as a clinitest inurines, may be useful in patients that assume 
galactose. The galactose-1-phosphate uridyltransferase assay for newborn screening [19] would prevent misdiagnoses in patients affected by galactosemia. Unfortunately a screening program for this disorder is not available in all countries.

\section{Competing interests}

The authors declare no competing interest.

\section{Authors' contribution}

RDC, CU, FS, EA and CP followed the patient and made the diagnosis, PV was the consultant hepatologist, GP was the consultant metabolic physician, RDC and GP wrote the paper. All authors read and approved the final manuscript.

\section{Author details}

'Department of Pediatrics, Federico II University, Via S. Pansini 5, 80131

Naples, Italy. ${ }^{2}$ Department of Pediatrics, University of Salerno, Salerno, Italy.

Received: 30 August 2012 Accepted: 11 September 2012

Published: 19 September 2012

\section{References}

1. Bosch AM: Classical galactosemia revisited. J Inherit Metab Dis 2006, 29:516-525.

2. Widger J, O'Toole J, Geoghegan O, O'Keefe M, Manning R: Diet and visually significant cataracts in galactosaemia: is regular follow up necessary? J Inherit Metab Dis 2010, 33:129-132.

3. Busiello R, Adriani M, Locatelli F, Galgani M, Fimiani G, Clementi R, Ursini MV, Racioppi L, Pignata C: Atypical features of familial hemophagocytic lymphohistiocytosis. Blood 2004, 103:4610-4612.

4. Capalbo D, Fusco A, Aloj G, Improda N, Vitiello L, Dianzani U, Betterle C, Salerno M, Pignata C: High intrafamilial variability in autoimmune polyendocrinopathy-candidiasis-ectodermal dystrophy: a case study. J Endocrinol Invest 2012, 35:77-81.

5. Capalbo D, Mazza C, Giordano R, Improda N, Arvat E, Cervato S, Morlin L, Pignata C, Betterle C, Salerno M: Molecular background and genotypephenotype correlation in autoimmune-polyendocrinopathy-candidiasisectodermal-distrophy patients from Campania and in their relatives. J Endocrinol Invest 2012, 35:169-173.

6. Van Karnebeek CD, Stockler S: Treatable inborn errors of metabolism causing intellectual disability: a systematic literature review. Mol Genet Metab 2012, 105:368-381.

7. Melis D, Parenti G, Della Casa R, Sibilio M, Romano A, Di Salle F, Elefante R, Mansi G, Santoro L, Perretti A, Paludetto R, Sequino L, Andria G: Brain damage in glycogen storage disease type I. J Pediatr 2004, 144:637-642.

8. Santamaria F, Andreucci MV, Parenti G, Polverino M, Viggiano D, Montella S, Cesaro A, Ciccarelli R, Capaldo B, Andria G: Upper airway obstructive disease in mucopolysaccharidoses: polysomnography, computed tomography and nasal endoscopy findings. J Inherit Metab Dis 2007, 30:743-749.

9. Santamaria F, Brancaccio G, Parenti G, Francalanci P, Squitieri C, Sebastio G, Dionisi-Vici C, D'argenio P, Andria G, Parisi F: Recurrent fatal pulmonary alveolar proteinosis after heart-lung transplantation in a child with lysinuric protein intolerance. J Pediatr 2004, 145:268-272.

10. Santamaria F, Parenti G, Guidi G, Filocamo M, Strisciuglio P, Grillo G, Farina V, Sarnelli P, Rizzolo MG, Rotondo A, Andria G: Pulmonary manifestations of Gaucher disease: an increased risk for L444P homozygotes? Am J Respir Crit Care Med 1998, 157:985-989.

11. Montella S, Maglione M, Bruzzese D, Mollica C, Pignata C, Aloj G, Manna A, Esposito A, Mirra V, Santamaria F: Magnetic resonance imaging is an accurate and reliable method to evaluate non-cystic fibrosis paediatric lung disease. Respirology 2012, 17:87-91.

12. Fecarotta S, Amitrano M, Romano A, Della Casa R, Bruschini D, Astarita L, Parenti G, Andria G: The videofluoroscopic swallowing study shows a sustained improvement of dysphagia in children with Niemann-Pick disease type C after therapy with miglustat. Am J Med Genet A 2011, 155:540-547.

13. Melis D, Fulceri R, Parenti G, Marcolongo P, Gatti R, Parini R, Riva E, Della Casa R, Zammarchi E, Andria G, Benedetti A: Genotype/phenotype correlation in glycogen storage disease type $1 \mathrm{~b}$ : a multicentre study and review of the literature. Eur J Pediatr 2005, 164:501-508.

14. Melis D, Parenti G, Della Casa R, Sibilio M, Berni Canani R, Terrin G, Cucchiara $\mathrm{S}$, Andria G: Crohn's-like ileo-colitis in patients affected by glycogen storage disease lb: two years' follow-up of patients with a wide spectrum of gastrointestinal signs. Acta Paediatr 2003, 92:1415-1421.

15. Scarpa M, Barone R, Fiumara A, Astarita L, Parenti G, Rampazzo A, Sala S, Sorge G, Parini R: Mucopolysaccharidosis VI: the Italian experience. Eur J Pediatr 2009, 168:1203-1206.

16. Bembi B, Cerini E, Danesino C, Donati MA, Gasperini S, Morandi L, Musumeci O, Parenti G, Ravaglia S, Seidita F, Toscano A, Vianello A: Diagnosis of glycogenosis type II. Neurology 2008, 71:S4-S11.

17. Bembi B, Cerini E, Danesino C, Donati MA, Gasperini S, Morandi L, Musumeci O, Parenti G, Ravaglia S, Seidita F, Toscano A, Vianello A: Management and treatment of glycogenosis type II. Neurology 2008, 71:S12-S36

18. Parenti G, Andria G: Pompe disease: from new views on pathophysiology to innovative therapeutic strategies. Curr Pharm Biotechnol 2011, 12:902-915.

19. Freer $D E$, Ficicioglu C, Finegold D: Newborn screening for galactosemia: a review of 5 years of data and audit of a revised reporting approach. Clin Chem 2010, 56:437-444.

doi:10.1186/1824-7288-38-47

Cite this article as: Della Casa et al:: A case of galactosemia

misdiagnosed as cow's milk intolerance. Italian Journal of Pediatrics

\section{Submit your next manuscript to BioMed Central and take full advantage of:}

- Convenient online submission

- Thorough peer review

- No space constraints or color figure charges

- Immediate publication on acceptance

- Inclusion in PubMed, CAS, Scopus and Google Scholar

- Research which is freely available for redistribution
Biomed Central 